\title{
Responses of Forest Ecosystems to Nitrogen Deposition
}

\author{
Frank S. Gilliam $\mathbb{D}$
}

Citation: Gilliam, F.S. Responses of

Forest Ecosystems to Nitrogen

Deposition. Forests 2021, 12, 1190.

https://doi.org/10.3390/f12091190

Received: 24 August 2021

Accepted: 31 August 2021

Published: 2 September 2021

Publisher's Note: MDPI stays neutral with regard to jurisdictional claims in published maps and institutional affiliations.

\author{
Department of Biology, University of West Florida, Pensacola, FL 32514, USA; fgilliam@uwf.edu
}

Environmental legislation in countries around the world has led to notable recent declines in the atmospheric deposition of nitrogen $(\mathrm{N})$, although most decreases relate to oxidized $\mathrm{N}$, with reduced $\mathrm{N}$ increasing in many areas [1]. Still, deposition of $\mathrm{N}$ remains high in many regions globally. For areas where chronic atmospheric deposition of $\mathrm{N}$ has led to $\mathrm{N}$ saturation, excess $\mathrm{N}$ chronically threatens the structure and function of ecosystems. Indeed, critical loads for $\mathrm{N}$ remain widely exceeded for many forests, leading to a variety of deleterious effects, including loss of biodiversity and altered biogeochemical cycles, all of which threaten the sustainability of impacted forests [2]. It is likely that the recovery of $\mathrm{N}$-impacted sites might require extended periods of time, especially in locations where base cations, such as $\mathrm{Ca}^{++}$, have been depleted by accelerated $\mathrm{NO}_{3}{ }^{-}$ leaching. Thus, understanding the potential responses of forest ecosystems to $\mathrm{N}$ deposition remains essential.

This Special Issue of Forests explores the multifaceted responses of forest ecosystems to both increases and decreases in $\mathrm{N}$ deposition on a global scale. This includes effects on plants and plant assemblages, as well as effects of $\mathrm{N}$ on forest biogeochemistry, and comprises studies from Asia, Europe, and North America.

Certainly, the fundamental paradigms of $\mathrm{N}$ cycling in terrestrial ecosystems have shifted greatly over the past several decades [3], and $\mathrm{N}$ has been the focus of extensive research as both basic and applied science. More recently and more specifically this has been carried out by biogeochemists, extending from the discovery of $\mathrm{N}$ as an element in 1772 , to its central place in von Liebig's Law of Minimum for plant growth articulated in 1827 , to the discovery of symbiotic $\mathrm{N}$ fixation in 1888 , to the development of the HaberBosch process in 1913 (initiating of its use as fertilizer in crop production), and finally to the present awareness that excess $\mathrm{N}$ in the environment can alter the structure and function of ecosystems [4].

Chronic $\mathrm{N}$ deposition has been an environmental threat throughout most of Asia. In Japan, research has demonstrated that effects of excess $\mathrm{N}$ can include trophic interactions involving tree foliar tissue and defoliating insects, which can be particularly notable in $\mathrm{N}_{2}$-fixing trees [5]. Excess $\mathrm{N}$ also influences the biogeochemical cycles of tropical Asian forests. Experimental additions of $\mathrm{N}$ significantly inhibited mineralization of soil carbon (C) in tropical forest soils of southern China (the Dinghushan Biosphere Reserve-DHSBR), increasing concentrations of dissolved organic carbon [6]. Deposition of $\mathrm{N}$ can interact with that of other nutrients, e.g., phosphorus (P), to alter plant tissue nutrient stoichiometry, especially in humid tropical forests that are typically N-rich, but limited by $\mathrm{P}$. Another factorial field experiment at DHSBR demonstrated that additions of $\mathrm{P}$, rather than $\mathrm{N}$, greatly altered foliar $\mathrm{N}$ and $\mathrm{P}$ concentrations in understory plants [7].

Europe has long experienced excess $\mathrm{N}$ deposition from increased emissions of gaseous $\mathrm{N}$ from industrial, domestic, and agricultural sources. Long-term ( 30 yr) data from the Australian Alps has shown that, although $\mathrm{N}$ deposition approximated or exceeded critical loads, $>80 \%$ of this was retained in the ecosystem, maintaining lower hydrologic $\mathrm{N}$ loss; tree growth was identified as the main sink for $\mathrm{N}$ [8]. Indeed, forest dynamics often mitigate effects of high $\mathrm{N}$ deposition, including the response of soil nutrient cations, i.e., $\mathrm{Ca}^{++}, \mathrm{Mg}^{++}$, and $\mathrm{K}^{+}$. Work in hardwood and conifer stands of central Germany found 
significant differences between these stand types regarding the effects of excess $\mathrm{N}$ on the biogeochemical cycling of these essential plant nutrients [9].

Most research on effects of excess $\mathrm{N}$ on forest ecosystems has been carried out via plot-based field designs which have the advantage of being fully factorial and involving replications, but the disadvantage of lacking realistic simulations of increased deposition of $\mathrm{N}$ from the atmosphere. Accordingly, whole-watershed manipulations, wherein $\mathrm{N}$ is applied from rotary or fixed-wing aircraft, are rare. Research at the Fernow Experimental Forest (FEF), Tucker County, West Virginia, comprises both plot-based and whole-watershed approaches, with aerial additions of $\left(\mathrm{NH}_{4}\right)_{2} \mathrm{SO}_{4}$ at $35 \mathrm{~kg} \mathrm{~N} \mathrm{ha}^{-1} \mathrm{yr}^{-1}$ to the treatment watershed beginning in 1989. Although this site is an eastern deciduous forest, results from over a quarter century have relevant implications for other forest types, as well $[10,11]$.

Past and ongoing work at FEF is highly varied with respect to forest response variables. An unexpected outcome has been the discovery that excess $\mathrm{N}$ can make some hardwood species more susceptible to damage from storm-related winds, which has implications for climate change and the future of impacted forests [12]. Excess $\mathrm{N}$ can also greatly alter the species composition and diversity of forest herbaceous communities, which is where up to $90 \%$ of plant diversity is found in forest ecosystems $[10,13,14]$. Recent efforts have demonstrated that this response can vary greatly with stand age and dominant tree species [15]. Not surprisingly, the response of forest trees to excess $\mathrm{N}$ can be highly species specific, and work at FEF has shown that several hardwood species, such as sweet birch (Betula lenta L.), black cherry (Prunus serotina Ehrh.), and red maple (Acer rubrum L.) responded positively to $\mathrm{N}$ additions, whereas yellow poplar (Liriodendron tulipifera $\mathrm{L}$.) responded negatively [16]. These species-specific responses have implications for ecosystem-level effects of $\mathrm{N}$ on forests, as some hardwood species, especially sugar maple (Acer saccharum L.), can facilitate greater loss of $\mathrm{N}$, via leaching of $\mathrm{NO}_{3}{ }^{-}$, by enhancing rates of net nitrification [17].

Recent studies have speculated about the future of $\mathrm{N}$-impacted forest ecosystems under conditions of decreased N deposition [1,18-20]. In 2019, aerial applications of NS ceased after $30 \mathrm{yr}$ of treatment at FEF. This new phase of research at FEF now allows researchers the opportunity to test these predictions empirically [21], further advancing our knowledge and understanding of the complexity of $\mathrm{N}$ biogeochemistry in forest ecosystems.

Funding: This research received no external funding.

Acknowledgments: I gratefully acknowledge the work and contributions of the authors and coauthors of the papers featured in this Special Issue. I also thank Special Issue Editor for invaluable assistance throughout the publishing process.

Conflicts of Interest: The author declares no conflict of interest.

\section{References}

1. Gilliam, F.S.; Burns, D.A.; Driscoll, C.T.; Frey, S.D.; Lovett, G.M.; Watmough, S.A. Decreased atmospheric nitrogen deposition in eastern North America: Predicted responses of forest ecosystems. Environ. Pollut. 2019, 244, 560-574. [CrossRef] [PubMed]

2. Pardo, L.H.; Fenn, M.E.; Goodale, C.L.; Geiser, L.H.; Driscoll, C.T.; Allen, E.B.; Baron, J.S.; Bobbink, R.; Bowman, W.D.; Clark, C.M.; et al. Effects of nitrogen deposition and empirical nitrogen critical loads for ecoregions of the United States. Ecol. Appl. 2011, 21, 3049-3082. [CrossRef]

3. Bobbink, R.; Hicks, K.; Galloway, J.; Spranger, T.; Alkemade, R.; Ashmore, M.; Bustamante, M.; Cinderby, S.; Davidson, E.; Dentener, F.; et al. Global assessment of nitrogen deposition effects on terrestrial plant diversity effects of terrestrial ecosystems: A synthesis. Ecol. Appl. 2010, 20, 30-59. [CrossRef] [PubMed]

4. Galloway, J.N.; Dentener, F.J.; Capone, D.G.; Boyer, E.W.; Howarth, R.W.; Seitzinger, S.P.; Asner, G.P.; Cleveland, C.C.; Green, P.A.; Holland, E.A.; et al. Nitrogen cycles: Past, present, and future. Biogeochemistry 2004, 70, 153-226. [CrossRef]

5. Lee, J.; Nakamura, M.; Hiura, T. Effects of large-scale nitrogen fertilization on insect-plant interactions in the canopy of tall alder trees with $\mathrm{N}_{2}$-fixing traits in a cool temperate forest. Forests 2021, 12, 210. [CrossRef]

6. Lu, X.; Mao, Q.; Wang, Z.; Mori, T.; Mo, J.; Su, F.; Pang, Z. Long-term nitrogen addition decreases soil carbon mineralization in an N-rich primary tropical forest. Forests 2021, 12, 734. [CrossRef]

7. Mao, Q.; Chen, H.; Wang, C.; Pang, Z.; Mo, J.; Lu, X. Effect of long-term nitrogen and phosphorus additions on understory plant nutrients in a primary tropical forest. Forests 2021, 12, 803. [CrossRef] 
8. Dirnböck, T.; Brielmann, H.; Djukic, I.; Geiger, S.; Hartmann, A.; Humer, F.; Kobler, J.; Kralik, M.; Liu, Y.; Mirtl, M.; et al. Longand short-term inorganic nitrogen runoff from a karst catchment in Austria. Forests 2020, 11, 1112. [CrossRef]

9. Achilles, F.; Tischer, A.; Bernhardt-Römermann, M.; Chmara, I.; Achilles, M.; Michalzik, B. Effects of moderate nitrate and low sulphate depositions on the status of soil base cation pools and recent mineral soil acidification at forest conversion sites with European beech ("Green Eyes") embedded in Norway spruce and Scots pine stands. Forests 2021, 12, 573. [CrossRef]

10. Gilliam, F.S.; Welch, N.T.; Phillips, A.H.; Billmyer, J.H.; Peterjohn, W.T.; Fowler, Z.K.; Walter, C.A.; Burnham, M.B.; May, J.D.; Adams, M.B. Twenty-five year response of the herbaceous layer of a temperate hardwood forest to elevated nitrogen deposition. Ecosphere 2016, 7, e01250. [CrossRef]

11. Gilliam, F.S.; Walter, C.A.; Adams, M.B.; Peterjohn, W.T. Nitrogen (N) dynamics in the mineral soil of a Central Appalachian hardwood forest during a quarter century of whole-watershed $\mathrm{N}$ additions. Ecosystems 2018, 21, 1489-1504. [CrossRef]

12. Walter, C.A.; Fowler, Z.K.; Adams, M.B.; Burnham, M.B.; McNeil, B.E.; Peterjohn, W.T. Nitrogen Fertilization increases Windstorm Damage in an Aggrading Forest. Forests 2021, 12, 443. [CrossRef]

13. Gilliam, F.S. Response of the herbaceous layer of forest ecosystems to excess nitrogen deposition. J. Ecol. 2006, 94, 1176-1191. [CrossRef]

14. Gilliam, F.S. The Herbaceous Layer in Forests of Eastern North America, 2nd ed.; Oxford University Press, Inc.: New York, NY, USA, 2014.

15. Smith, L.J.; Stephan, K. Nitrogen fertilization, stand age, and overstory tree species impact the herbaceous layer in a Central Appalachian hardwood forest. Forests 2021, 12, 829. [CrossRef]

16. Storm, A.; Adams, M.B.; Schuler, J. Long-term projection of species-specific responses to chronic additions of nitrogen, sulfur, and lime. Forests 2021, 12, 1069. [CrossRef]

17. Burnham, M.B.; Christ, M.J.; Adams, M.B.; Peterjohn, W.T. Assessing the linkages between tree species composition and stream water nitrate in a reference watershed in Central Appalachia. Forests 2021, 12, 1116. [CrossRef]

18. Schmitz, A.; Sanders, T.G.M.; Bolte, A.; Bussotti, F.; Dirnböck, T.; Johnson, J.; Peñuelas, J.; Pollastrini, M.; Prescher, A.-K.; Sardans, J.; et al. Responses of forest ecosystems in Europe to decreasing nitrogen deposition. Environ. Pollut. 2019, 244, 980-994. [CrossRef] [PubMed]

19. Chiwa, M. Long-term changes in atmospheric nitrogen deposition and stream water nitrate leaching from forested watersheds in western Japan. Environ. Pollut. 2021, 287, 117634. [CrossRef] [PubMed]

20. Reid, H.; Aherne, J. Staggering reductions in atmospheric nitrogen dioxide across Canada in response to legislated transportation emissions reductions. Atmos. Environ. 2016, 146, 252-260. [CrossRef]

21. Gilliam, F.S. Response of temperate forest ecosystems under decreased nitrogen deposition: Research challenges and opportunities. Forests 2021, 12, 509. [CrossRef] 